\title{
Description of the male of Hymenoepimecis bicolor (Brullé, 1846) (Hymenoptera, Ichneumonidae, Pimplinae)
}

\author{
J. F. Sobczak ${ }^{a *}$, A. P. S. Loffredo ${ }^{b}$, A. M. Penteado-Dias ${ }^{b}$, Y. F. Messas ${ }^{c}$ and D. G. Pádua \\ anstituto de Ciências Exatas e da Natureza - ICEN, Universidade da Integração Internacional da Lusofonia Afro-Brasileira \\ - UNILAB, Rodovia CE 060, Km 51, CEP 62785-000, Acarape, CE, Brasil

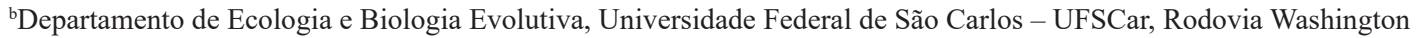 \\ Luís, Km 235, CP 676, CEP 13565-905, São Carlos, SP, Brasil \\ 'Departamento de Biologia Animal, Universidade Estadual de Campinas - UNICAMP, Rua Monteiro Lobato, 255, \\ CEP 13083-862, Campinas, SP, Brasil \\ dPrograma de Pós-graduação em Entomologia, Instituto Nacional de Pesquisas da Amazônia - INPA, Av. André Araújo, \\ 2936, CEP 69060-001, Manaus, AM, Brasil \\ *e-mail: jobczak@unilab.edu.br
}

Received: April 21, 2017 - Accepted: August 4, 2017 - Distributed: February 28, 2019

(With 1 figure)

Wasps of the Polysphincta genus-group (sensu Wahl and Gauld, 1998 or Polysphinctini sensu Towens, 1969) presents more than 200 described species (Matsumoto, 2016) exclusively koinobiont ectoparasitoids of several spider families (Dubois et al., 2002; Gauld and Dubois, 2006; Matsumoto, 2016). Most of taxonomic descriptions of polysphinctine wasps were based on female individuals, principally due to the presence of the ovipositor (see Gauld, 1991; Gauld et al., 1998, 2002). Meantime, some interactions of these hymenopteran with spiders were documented only with emerged males (e. g. Sobczak et al., 2011, 2017; Sobczak, 2012), hindering the association between males and females within the group. Sobczak et al. (2017) emphasized the importance of detailed descriptions of male genitalia to support future reviews and phylogenetic studies.

Within Polysphincta group, Hymenoepimecis Viereck, 1912 (Ichneumonidae) wasps occur in the Neotropical region, from Mexico to Southern of Brazil (Gauld, 2000; Gauld and Dubois, 2006; Gonzaga and Sobczak, 2007; Loffredo and Penteado-Dias, 2009; Sobczak et al., 2009; Pádua et al., 2015). The species of this genus are characterized by the presence of a pocket-like structure on the pronotum; a mesopleuron with epicnemial carina vestigial or absent; the absence of the vein $3 \mathrm{rs}-\mathrm{m}$ in fore wing (Gauld, 1991); yellowish brown color and large ocelli (Gauld and Dubois, 2006).

Currently, Hymenoepimecis is composed by 20 valid species (Yu et al., 2012; Pádua et al., 2015), of which 12 are known as parasitoids of spiders (summarized in Pádua et al., 2016). Regarding these interactions, it is known that the larva of some wasp species can induce the host spider to construct a modified web (cocoon web), which is subsequently used as substrate for the wasp larva's cocoon (Eberhard, 2000a, b, 2001; Sobczak et al., 2009, 2014; Gonzaga et al., 2010;). The modified web is usually more stable and resistant than the normal web, increasing the wasp survival (Eberhard, 2001). Gonzaga et al. (2010) described the interaction involving the spider Nephila clavipes (Linnaeus, 1767) (Araneidae) and the wasp Hymenoepimecis bicolor (Brullé, 1846), which follows the pattern of behavioral manipulation described above (Gonzaga et al., 2010).

Although relative well investigated on its natural history and ecology, taxonomy of $H$. bicolor is still restricted to the female description. Thus, in this study we described and illustrated the male of $H$. bicolor, with detailed description of genital capsule.

To describe the adult male of $H$. bicolor and compare its morphology with female's characteristics, specimens deposited at the Invertebrate Collection of the Instituto Nacional de Pesquisas da Amazônia, Manaus (INPA; curator M. L. Oliveira) were examined. It was used the morphological terminology and description style according to Gauld (1991), and terminology for male genitalia followed Snodgrass (1941). Pictures were taken with a Leica DFC295 digital camera attached to a Leica M205C stereomicroscope and combined with the software Leica Application Suite (Version 4.0.0). The male genitalia were extracted and submerged in $10 \%$ potassium hydroxide at room temperature for clarification. To draw the genital capsule, a Leica DM750 microscope, with posterior digital vectorization was used.

\section{Taxonomy}

Hymenoepimecis bicolor (Brullé, 1846) (Figures 1A, B) Epimecis bicolor Brullé, 1846: 113.

Hymenoepimecis bicolor (Brullé) Viereck, 1912: 149.

Male (Figure 1A): Length: 8.9-14 mm. Fore wings: 6.6-8.9 mm. Antenna with 33-38 flagellomeres, lower face about 0.7-1.0 times as broad as high, with scattered hairs, coriaceous and striated transversally, presence of small tubercle below the base of scapus; head in dorsal view (Figure 1B) with long gena, posterior ocelli separated from eyes by 0.75-1.2 times its own maximum diameter. The distance from tegula to head is about 0.6-0.9 times the distance from tegula to hind margin of propodeum, scutellum in profile convex, mesopleuron smooth and polished; propodeum smooth, polished with two lateral longitudinal carinae only posteriorly, and opening pocket-like structure with 

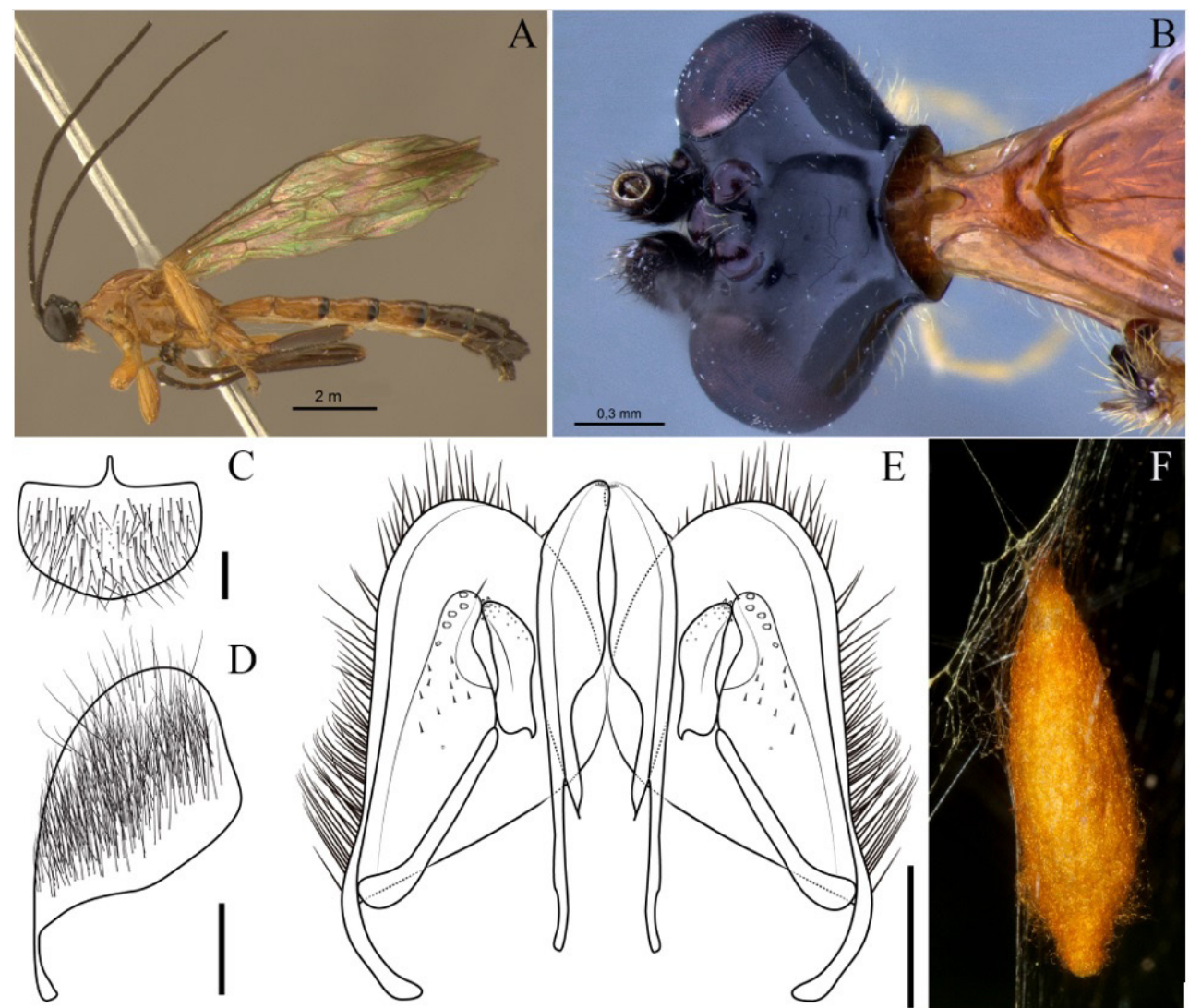

Figure 1. (A, B). Hymenoepimecis bicolor (Brullé, 1846) ठ̊: (A) habitus; (B) head and pronotum, dorsal view; (C-E) Hypopygium and genitalia: (C) hypopygium; (D) genitalia, lateral view; (E) genitalia, ventral view; (F) cocoon. Scale bars: $(\mathrm{C}-\mathrm{E})=200 \mu \mathrm{m}$.

a longitudinal opening in the central surface. Metapleuron and propodeum with scattered hairs, sub metapleural carina absent. Fore wing with cu-a interstitial to base of Rs \& M, 2rs-m about 0.25-0.5 times as long as abscissa of M between 2rs-m and 2m-cua, vein 3rs-m absent; hind wing with distal abscissa of $\mathrm{Cu} 1$ meeting $\mathrm{cu}-\mathrm{a}$ closer to $M$ than $1 A$. Hind tibia plus tarsus $0.55-0.7$ times the fore wing length. Metasoma slender, tergite I 2.6 times as long as posteriorly broad, with convergent lateral carinae present only anteriorly; sternite I with an apically acute, thorn-like ventral projection posteriorly, tergite II-IV 1.2-1.4 times as long as posteriorly broad with presence of two smooth tubercles. Subgenital plate as long as broad, with bristles evenly; sternal apodeme narrow, about 0.2 times longer than sternum (sternal apodeme plus sterno) (Figure 1C); genital capsule (Figures 1D, E) with paramere rounded apically, narrower than parameral lamina, with dense bristles; volsellar lamina with few bristles spaced subapically; cuspis robust, with tooth in lateral and apical parts and a bristle at the apex; digitus narrow, 0.40-0.46 times the length of cuspis plus volsellar lamina, with tooth in the apex, apex rounded dorsally and angulated ventrally, its basal region slightly larger than apical region; aedeagus (including aedeagal apodeme) $0.90-0.95$ times the length of paramere plus parameral lamina (including the parameral apodeme); ergot about 0.27-0.37 times the length of aedeagus.

Coloration: Body honey yellow. Head black, the most part of clypeus pale yellow. Tergites II-V orange with apical margin black, VI + black; sternite I smooth, brownish; II-VI light brown and coriaceous. Fore and mid legs orange, hind leg with femur, tibia and tarsi black. Wings yellowish, fore wing with apex blackish, pterostigma yellow.

Cocoon (Figure 1F): fusiform, light golden yellow (Figure 1C), remains attached to modified web of the host. To get out from the cocoon, the adult wasp uses the jaws to cut the apical part.

Variation: face smooth; opening pocket like structure without a longitudinal opening in the central surface; hind wing with distal abscissa of $\mathrm{Cu} 1$ meeting $\mathrm{cu}$ - $\mathrm{a}$ equidistant between $1 A$ and $M$; tergites II-IV orange with two black spots in the distal corners; tergite V entirely black.

Examined material: Amazonas: Manaus, Reserva 1208, Fazenda Esteio, PDBFF, 02²2’34’S/5952’39’W, 09.vii.1985, Malaise (Bert Klein leg.), 1 ô, INPA; Parque Nacional Jaú, Rio Carabinani, Igarapé Preguição, 20-29.vi. 1994 (L.S. Aquino leg.), 1 त̃, INPA; Borba, Rio Abacaxis, 27-29.v.2008, Malaise (J.A. Rafael et al. Leg.), 
1 ภे, INPA; Itacoatiara, Madeireira Mil, 16.vii.1999, Malaise (J. Vidal leg.), 1 ${ }^{\lambda}$, INPA; Maués, Rio Abacaxis,

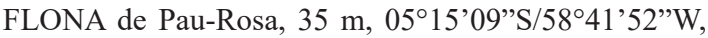
26-28.v.2008, Malaise (J.A. Rafael leg.), $1 \hat{\jmath}$, INPA; Tonantins, Igarapé Manaquinha, $02^{\circ} 50^{\prime} 15^{\prime \prime} \mathrm{S} / 67^{\circ} 46^{\prime} 30^{\prime \prime} \mathrm{W}, 16-20$. ix.2005, Malaise (J.A. Rafael \& F.F. Xavier Filho legs.), 1 ^ै, INPA. São Paulo: Gália, Estação Ecológica dos Caetetus, Trilha Z1, 28.ii-06.iii.2004, Malaise (J.F. Nunes col.), 1 के, INPA-HYM 031389, INPA; Luiz Antônio, Est. Ecológica de Jatai, Mata ciliar, Ponto I, $21^{\circ} 36^{\prime} 47^{\prime \prime S} / 47^{\circ} 49^{\prime} 04^{\prime \prime}$, 30.i.2008, Light trap (R.I.R. Lara and team cols.), 1 ô, INPA. Total: 8 males.

Comments: The male genitalia of $H$. bicolor was compared to the other species of which male genitalia has been described so far, H. duckensis Pádua \& Onody, 2015, H. manauara Pádua \& Oliveira, 2015, H. ribeiroi Pádua \& Sockzak, 2015, and H. uberensis Pádua \& Onody, 2015 (see Pádua et al., 2015). It was observed that $H$. bicolor differs from $H$. duckensis by having the volsellar lamina with few bristles spaced subapically and cuspis with bristles at the apex; H. duckensis do not have bristles at the apex in the cuspis and nor the volsellar lamina with many bristles spaced, except in posterior region. Hymenoepimecis bicolor differs from $H$. manauara, $H$. ribeiroi and $H$. uberensis essentially by the presence of cuspis with bristles at the apex (except $H$. manauara, that it is also present) and digitus narrow, rounded dorsally and angulated ventrally, with basal region slightly larger than apical region. Hymenoepimecis manauara have digitus enlarged apically and angulated basally, H. riberoi have cuspis without bristles in apex and digitus rounded apically and angulated basally, as wide as the basal region, and H. uberensis have cuspis without bristles in apex and digitus truncated apically and angulated basally. In addition to the morphological differences of the male genitalia compared in this study, the external morphological characteristics and staining of the male of H. bicolor is similar to the female and this species differs from the other Hymenoepimecis species by the following characteristics: fore wing hyaline yellowish, with apex blackish, metasoma orange, with posterior margins of tergites II-V narrowly black, tergites VI+ black, sternite I with a high, laterally compressed, nasute ventral protuberance, ovipositor 1.0-1.3 times as long as hind tibia.

\section{Acknowledgements}

We were financially supported by Instituto Nacional de Ciência e Tecnologia dos Hymenoptera Parasitoides da Região Sudeste Brasileira (HYMPAR/Sudeste $\mathrm{CNPq} / \mathrm{FAPESP} / \mathrm{CAPES}$ ), CNPq (research grants to J.F. Sobczak, A.P.S. Loffredo and A.M. Penteado-Dias), CNPq-Universal proc. 446473/2014-6 and FUNCAP BPI - proc. BP2-0107-00127.01.00/15 (research grants to J. F. Sobczak). We also thank CAPES Pró-Equipamentos DECEN, coordinated by Neusa Hamada, INPA, for the use of layer-photo microscopes and the Invertebrate Collection of INPA for the use of photographic equipment.

\section{References}

DUBOIS, J., ROLLARD, C., VILLEMANT, C. and GAULD, I.D., 2002. The phylogenetic position of parasitoids of spiders within Pimplinae (Hymenoptera, Ichneumonidae). In: F. SAMU and C.S. SZINETÁR, eds. Proceedings of the 20th European Colloquium of Arachnology, 2002, Budapest, Hungria. Budapest: Plant Protection Institute and Berzsenyi College Press, pp. 27-35.

EBERHARD, W.G., 2000a. The natural history and behavior of Hymenoepimecis argyraphaga (Hymenoptera: Ichneumonidae) a parasitoid of Plesiometa argyra (Araneae, Tetragnathidae). Journal of Hymenoptera Research, vol. 9, pp. 220-240.

EBERHARD, W.G., 2000b. Spider manipulation by a wasp larva. Nature, vol. 406, no. 6793, pp. 255-256. http://dx.doi. org/10.1038/35018636. PMid:10917517.

EBERHARD, W.G., 2001. Under the influence: webs and building behavior of Plesiometa argyra (Araneae, Tetragnathidae) when parasitized by Hymenoepimecis argyraphaga (Hymenoptera, Ichneumonidae). The Journal of Arachnology, vol. 29, no. 3, pp. 354-366. http://dx.doi.org/10.1636/0161-8202(2001)029[0354:UT IWAB]2.0.CO;2.

GAULD, I.D., 1991. The Ichneumonidae of Costa Rica, 1. Memoirs of the American Entomological Institute, vol. 47, pp. 1-589.

GAULD, I.D., 2000. The re-definition of pimpline genus Hymenoepimecis (Hymenoptera: Ichneumonidae) with a description of a plesiomorphic new Costa Rican species. Journal of Hymenoptera Research, vol. 9, pp. 213-219.

GAULD, I.D. and DUBOIS, J., 2006. Phylogeny of the Polysphincta group of genera (Hymenoptera: Ichneumonidae; Pimplinae): a taxonomic revision of spider ectoparasitoids. Systematic Entomology, vol. 31, no. 3, pp. 529-564. http://dx.doi. org/10.1111/j.1365-3113.2006.00334.x.

GAULD, I.D., MENJÍVAR, R., GONZALEZ, M.O. and MONRO, A., 2002. Guía para la identificación de los Pimplinae de cafetales bajo sombra de El Salvador (Hymenoptera: Ichneumonidae). London: The Natural History Museum, pp. 1-76.

GAULD, I.D., UGALDE, J.A. and HANSON, P., 1998. Guía de los Pimplinae de Costa Rica (Hymenoptera: Ichneumonidae). Revista de Biología Tropical, vol. 46, pp. 1-189.

GONZAGA, M.O. and SOBCZAK, J.F., 2007. Parasitoidinduced mortality of Araneus omnicolor (Araneae, Araneidae) by Hymenoepimecis sp. (Hymenoptera, Ichneumonidae) in Southeastern Brazil. Naturwissenschaften, vol. 94, no. 3, pp. 223-227. http:// dx.doi.org/10.1007/s00114-006-0177-z. PMid:17119908.

GONZAGA, M.O., SOBCZAK, J.F., PENTEADO-DIAS, A.M. and EBERHARD, W.G., 2010. Nephila clavipes (Araneae: Nephilidae) webs induced by the parasitoids Hymenoepimecis bicolor and H. robertsae (Hymenoptera: Ichneumonidae). Ethology Ecology and Evolution, vol. 22, no. 2, pp. 151-165. http://dx.doi. org/10.1080/03949371003707836.

LOFFREDO, A.P.S. and PENTEADO-DIAS, A.M., 2009. New species of Hymenoepimecis Viereck (Hymenoptera, Ichneumonidae, Pimplinae) from Brazilian Atlantic forest. Revista Brasileira de Entomologia, vol. 53, no. 1, pp. 11-14. http://dx.doi.org/10.1590/ S0085-56262009000100004

MATSUMOTO, R., 2016. Molecular phylogeny and systematics of the Polysphincta group of genera (Hymenoptera, Ichneumonidae, Pimplinae). Systematic Entomology, vol. 41, no. 4, pp. 854-864. http://dx.doi.org/10.1111/syen.12196. 
PÁDUA, D.G., OLIVEIRA, M.L., ONODY, H.C., SOBCZAK, J.F., SÄÄKSJÄRVI, I.E. and GÓMEZ, I.C., 2015. The Brazilian Amazonian species of Hymenoepimecis Viereck, 1912 (Hymenoptera: Ichneumonidae: Pimplinae). Zootaxa, vol. 4058, no. 2, pp. 175-194. http://dx.doi.org/10.11646/zootaxa.4058.2.2. PMid:26701518.

PÁDUA, D.G., SALVATIERRA, L., SOBCZAK, J.F. and OLIVEIRA, M.L., 2016. Parasitism of Hymenoepimecis manauara Pádua \& Oliveira (Hymenoptera: Ichneumonidae: Pimplinae) on Leucauge henryi Mello-Leitão (Araneae: Tetragnathidae) in Brazilian Amazonian. Biodiversity Data Journal, vol. 4, no. 4, pp. 1-10. http://dx.doi.org/10.3897/BDJ.4.e11219. PMid:28174511.

SNODGRASS, R.E., 1941. The male genitalia of Hymenoptera. Smithsonian Miscellaneous Collections, vol. 99, pp. 1-86.

SOBCZAK, J.F., 2012. Description of the male Hymenoepimecis japi Sobczak et al. 2009 (Hymenoptera, Ichneumonidae) parasitoid of Leucauge roseosignata Mello-Leitão 1943 (Araneae: Tetragnathidae). Brazilian Journal of Biology $=$ Revista Brasileira de Biologia, vol. 72, no. 4, pp. 945-947. http://dx.doi.org/10.1590/ S1519-69842012000500023.

SOBCZAK, J.F., LOFFREDO, A.P.S. and PENTEADO-DIAS, A.M., 2011. Description of the male of Hymenoepimecis veranii Loffredo \& Penteado-Dias, 2009 (Hymenoptera, Ichneumonidae, Pimplinae). Brazilian Journal of Biology $=$ Revista Brasileira de Biologia, vol. 71, no. 1, pp. 225-226. http://dx.doi.org/10.1590/ S1519-69842011000100035. PMid:21437425.

SOBCZAK, J.F., LOFFREDO, A.P.S., PENTEADO-DIAS, A.M. and GONZAGA, M.O., 2009. Two new species of
Hymenoepimecis (Hymenoptera: Ichneumonidae, Pimplinae) with notes on their spider hosts and behaviour manipulation. Journal of Natural History, vol. 43, no. 43-44, pp. 2691-2699. http://dx.doi.org/10.1080/00222930903244010.

SOBCZAK, J.F., MESSAS, Y.F. and PÁDUA, D.G., 2017. Parasitism of Zatypota riverai Gauld (Hymenoptera: Ichneumonidae: Pimplinae) on Anelosimus baeza Agnarsson (Araneae: Theridiidae) in northeast Brazil, with a description of the male. Zootaxa, vol. 4247, no. 1, pp. 78-82. http://dx.doi.org/10.11646/zootaxa.4247.1.11. PMid:28610092.

SOBCZAK, J.F., SOBCZAK, J.C.M.S.M., MESSAS, Y.F., SOUZA, H.S. and VASCONCELLOS-NETO, J., 2014. A new record of a host-parasitoid interaction: Hymenoepimecis veranii Lofredo \& Penteado-Dias, 2009 (Hymenoptera: Ichneumonidae) parasitizing Araneus orgaos Levi, 1991 (Araneae: Araneidae). Journal of Insect Behavior, vol. 27, no. 6, pp. 753-758. http:// dx.doi.org/10.1007/s10905-014-9467-z.

WAHL, D.B. and GAULD, I.D., 1998. The cladistics and higher classification of the Pimpliformes (Hymenoptera: Ichneumonidae). Systematic Entomology, vol. 23, no. 3, pp. 265-298. http://dx.doi. org/10.1046/j.1365-3113.1998.00057.x.

YU, D.S., VAN-ACHTERBERG, C. and HORSTMANN, K., 2012 [viewed 4 November 2016]. Ichneumonoidea 2011: taxonomy, biology, morphology and distribution [online]. Vancouver: Taxapad. Available from: http://www.taxapad.com 